\section{Further Education in Science and Technology in} Britain

IN a written answer in the House of Commons on December 12, the Minister of Education, Sir David Eccles, gave the number of full-time day students studying engineering in establishments of further education in England and Wales in 1954-55 as 7,455, compared with 6,944 in 1953-54; of these, 1,355 were on sandwich courses (compared with 746 in 1953-54), and there were 146,221 part-time day students $(131,376$ in 1953-54). For science the figures were 3,173 in $1954-55$ and 3,526 in $1953-54$, of whom 71 and 69 were on sandwich courses, and 11,010 part-time day students (10,791 in 1953-54). Enrolments in evening classes in mathematics and natural sciences totalled 429,282 in $1954-55$ and 410,400 in 1953-54; for engineoring and allied industries the corresponding figures are 278,466 and 269,564 . In grant-aided establishments of further education 1,209 full-time and 1,128 part-time day students of engineering were recorded as studying for university degrees in 1954-55, 2,229 full-time and 68,115 parttime for National Certificates; 185 full-time and 43,184 part-time for City and Guilds examinations and 2,199 full-time and 3,454 part-time for other examinations. For science the corresponding figures are 2,279 full-time and 5,184 part-time day students for university degrees ; 74 full-time and 10,829 parttime for National Certificates; 444 part-time for (yity and Guilds examinations; and 1,298 full-time and 4,262 part-time for other examinations.

\section{Technological Education in France}

Tre Paris Academy of Sciences, supporting proposals made by the Association des Professeurs de Mathématiques, the Union des Physiciens and the Union des Naturalistes, has submitted to the French Government a resolution in favour of certain reforms in scientific education (C.R. Acad. Sci., Paris, 243, $1811 ; 1956)$. The Academy, disturbed by the grave situation created by the growing shortage of scientists, engineers and technologists, and the inadequate number of young men embarking on a scientific career, points out the necessity for recruiting not only men with a vocation for the abstract sciences and mathematics, but also those with an aptitude for observation and experiment. The Academy therefore proposes that, in order to satisfy this dual requirement, matriculation examinations should not be such as to discourage from scientific careers young men not especially gifted in mathematics. It is also proposed that secondary schools should be less concerned with detailed instruction than with laying a firm foundation of basic principles; and that every effort be made to attract pupils to science by introducing them at an early age to the experimental method, by practical exercises and characteristic examples, to be reinforced at a later stage by more predominantly scientific instruction. Finally, it is proposed that every initiative be encouraged toward recruiting competent teachers even without diploma, and accepting students even without competitive examination, in view of the urgency of the need.

\section{Imperial College of Science and Technology,} 1954-55

THE forty-eighth annual report of the Governing Body of the Imperial College of Science and Technology (London) for the year 1954-55 (from the College) notes that appointments were made to the new chairs of applied science, with special reference to engineering, soil mechanics, heavy electrical engineering, physical chemistry, instrument technology, statistics, parasitology, applied geophysics and aeronautical structures, and to readerships in applied geochemistry, physical chemistry, mining and chemical engineering. A strong expansion committee has been appointed from among members of the Governing Body, and the physical expansion of the College is gathering momentum. An additional story over the Goldsmiths' Company Extension to the City and Guilds College and the Royal school of Mines was completed in April 1955 and, besides rolieving congestion due to the increased intake of engineering students, provides new accommodation for applied geophysics and applied geochemistry. A further extension of chemical engineering in connexion with a new aeronauties building was scheduled for occupation by the latter in October 1956, and by chemical engineering in December 1956. Rebuilding of the Imperial College Union was expected to be complete in September 1956, and an alteration in the Bessemer Laboratory of the Royal School of Mines to serve as a temporary house for the Mechanical Engineering Workshop and Materials Laboratory is already complete. 'Two stories are also being added to the single-story part of the Chemistry Department. These beginnings have all been made on sites already in possession of the College, and any further expansion by building awaits acquisition by the College of other parts of the 'island site' at present occupied by. other institulions. Details of staff changes are appended to the report together with a list of publications and brief notes on departmental research. of the 2,282 students (including 412 part-time) in 1954-55, 1,840 were from the United Kingdom, 256 from the British Commonwealth and 186 from other parts of the world. Of the total, 1,019 were postgraduate, 229 were from London and 870 from the Home Counties.

\section{Atom}

Atom, the monthly bulletin of the United Kingdom Atomic Energy Authority, is distributed to the staff of the Authority, to similar orgdnizations overseas, to industrial firms concerned with the exploitation of nuclear energy, to the Press and to those to whom a record of information on the work of the Authority may be useful. 'The first issue (November), consisting of twenty-four pages, contains a report of the events of October 17, when Her Majesty Queen Elizabeth II pressed the switch that allowed power from the Calder Hall nuclear power station to pass into the national grid. The report includes the Queen's speech and technical details of Calder ' $A$ ' station. Apart from short notes dealing with diamond irradiation, the new reactor school at Harwell, and LIDO, and abstracts of patents, the main contents are devoted to the addresses given by Sir Edwin Plowden and Sir John Cockeroft at the meeting of the International Bank for Reconstruction and Development held on September 27. Sir Edwin spoke on the development of the nuclear power programme in Britain and compared British plans with likely trends of development in other countries. Sir John referred to the economic background against which the United Kingdom programme is progressing and undertook in his speech the speculative and difficult task of looking five or ten years beyond the United Kingdom programme as planned until 1960. He concluded by stating that "it is certain that, with the great power of creative 